\title{
Business
}

$\begin{array}{ll}899 & \text { APSA President } \\ & \text { Intellectual } \\ & \text { Biography } \\ 906 & \text { APSA Announces New } \\ & \text { APSR Editors } \\ 908 & \text { 2016-2017 Minority } \\ & \text { Fellows } \\ 911 & \begin{array}{l}\text { 2016 Fund for Latino } \\ \text { Scholarship }\end{array} \\ 913 \text { Briefs } \\ 915 \text { Next in } P S\end{array}$
918 APSA Member of the Month
919 Congressional Fellowship Program
923 APSA Pracademic Fellowship
9282016 Small Research Grants
9332016 Annual Meeting
962 Gazette

\section{David A. Lake: Master Builder}

\author{
Danielle F. Jung, Emory University \\ Wendy H. Wong, University of Toronto
}

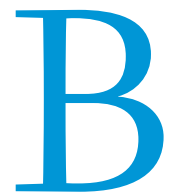

uilders make something original out of familiar raw materials, creating handiwork with a vision, a structure, and a logic to hold it all together. David A. Lake is a quintessential builder in all senses of the word. When Lake provides an answer, all of the intellectual buildings blocks are visible, the logic clear. He thinks big, but starts with the microfoundations of political phenomena to assemble the pieces in innovative ways.

Intellectually, Lake is and always has been motivated by big questions about how international order is constructed. Since his early days, he has worked to make sense of often complicated literatures in international relations to understand relations between states in the system, and the reasons for their decisions. In his research, he has rigorously parsed what it means for states to build order, arguing order is actively constructed. Most significantly, Lake has pioneered the use of relational contracting in political science to explore phenomena as diverse as trade (e.g., "Open Economy Politics"), security and insecurity (Entangling Relations), international hierarchy (Hierarchy in International Relations), conflict, NGOs, and most recently, statebuilding (The Statebuilder's Dilemma).

Institutionally, he has been a leader in the discipline, providing public goods for many different communities. Lake has served as president of the International Studies

Danielle F. Jung is assistant professor of political science at Emory University. She can be reached at danielle.jung@ emory.edu.

Wendy $\mathbf{H}$. Wong is associate professor of political science and director of the Trudeau Centre for Peace, Conflict and Justice, Munk School of Global Affairs, at the University of Toronto. She can be reached at wendyh.wong@ utoronto.ca.

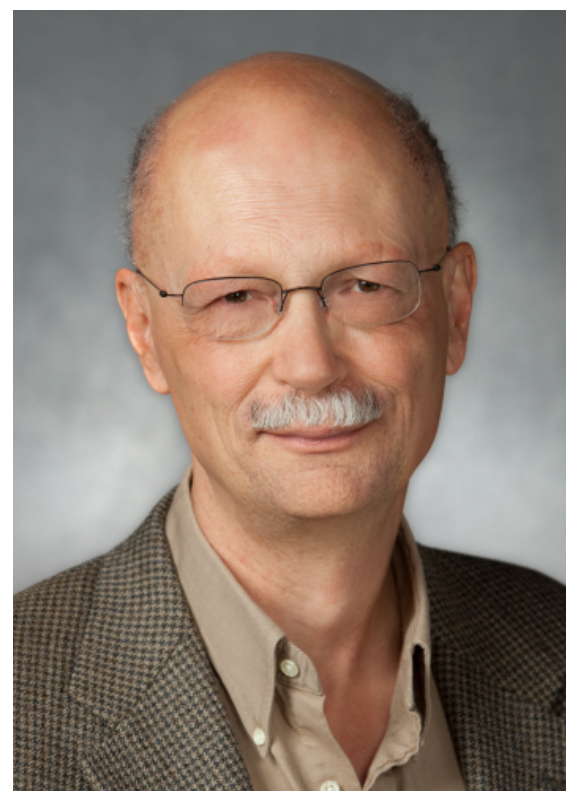

\section{6-2017 APSA President}

$$
\text { David A. Lake }
$$

Jerri-Ann and Gary E. Jacobs

Professor of Social Sciences and

Distinguished Professor

of Political Science,

University of California, San Diego

Association and now the American Political Science Association, coedited the flagship international relations journal International Organization, and held major senior administrative positions at University of California, San Diego (UCSD). Lake also shepherded the founding of the influential International Political Economy Society (IPES), whose meetings are enthusiastically attended and create opportunities for junior and senior scholars to mingle in a tight-knit community.
Collegially, Lake is generous with his time and open-minded in his knowledge and curiosity, taking the time to build up and build on nascent ideas. He has mentored scores of students and colleagues, including many whose work does not align completely-or at all-with his own research agenda; yet, he never passes up the chance to help make arguments better on the author's own terms. He reads widely and deeply, and does not hesitate to expound on the importance of ancient ruler Sargon of Akkad in the same breath as discussing the intricacies of contract theory.

In the spirit of full disclosure, we are Lake's former students at the University of California, San Diego. While the two of us work from very different traditions and methodologies, we have also coauthored since graduate school, in large part because of the lessons Lake taught us about building knowledge through collaboration. We aim in this essay to convey Lake's insightfulness, generosity, and commitment to scholarship and mentoring, in addition to the development of international relations within political science as he takes the helm of our association.

We take this opportunity to share the various dimensions of Lake's role as a builder of political science and political scientists. Given the breadth of his publications (more than 60 articles and chapters, four solo-authored books, and ten edited volumes to date) with a popular undergraduate textbook, this is admittedly a challenging task. His work has re-oriented new and existing scholars to the usefulness of rational choice frameworks in political science across many literatures. In exploring his publication record, we also highlight his simultaneous, extensive service to the field that began long before this APSA 
presidency. We conclude with what we (and his many students, colleagues, and friends in the discipline) know best about him: Lake as mentor, teacher, and collaborator.

\section{EARLY DAYS: LAYING THE GROUNDWORK}

Lake received his $\mathrm{PhD}$ from Cornell University in 1984, where he began his continuous exploration of the major dynamics of the international political system. The late 1970 s were an exciting time to start graduate studies in IR, and Cornell was a stimulating atmosphere to drink the deep with Mastanduno and Ikenberry would eventually lead to collaboration and publication long after their fellowships ended.

As an assistant professor at University of California, Los Angeles (UCLA), Lake continued building communities to sharpen his theoretical growth. Together with Jeffry Frieden, Ron Rogowski, Michael Wallerstein, and Art Stein, he was a core member of a diverse, informal but spirited political economy lunch group. They brought in other faculty, including comparativists (Barbara Geddes, Miriam Golden, George Tsebelis) and economists (in particular, Jack Hirshleifer), state-society relations ("Towards a Realist Theory of State Action").

By 1993, Lake's intellectual frustration was evident. Still intrigued by the question and the intuition at the heart of HST, he continued to bristle at the notion that structure is exogenous and that the powerful have distinct structurally derived interests. He criticized HST, including his own work ("Leadership, Hegemony, and the International Economy: Naked Emperor or Tattered Monarch with Potential?"), for its inability so far to derive a deductive foundation that produced a prediction that hegemons

\section{Intellectually, Lake is and always has been motivated by big questions about how international order is constructed... In his research, he has rigorously parsed what it means for states to build order, arguing order is actively constructed.}

intellectual waters. Some of the modern milestone texts of the subfield were being hammered out; students read Gilpin's U.S. Power and the Multinational Corporation and Waltz's just released Theory of International Politics in seminar. Katzenstein's Between Power and Plenty had recently been published, and Small States and World Markets was in progress. Lake took seminars with Peter Katzenstein, later a member of his dissertation committee, as well as his advisor Richard Rosecrance. This period fed directly into Lake's inclination toward tackling the links between domestic and international politics that remain one of the themes in his scholarship.

At Cornell, Lake carefully observed how faculty understood their roles. Lake cites Katzenstein as a particularly salient exemplar of a productive scholar and tireless mentor. $\mathrm{He}$ observed the way that Katzenstein worked with graduate students to help them build a professional career, spending hours on the intangibles of the job that are so important for a young academic's later success. In many ways, as we discuss later, Lake carries those lessons into his own successful career as a mentor and advisor.

Later, as a pre-doctoral foreign policy fellow at the Brookings Institute, Lake found a lively intellectual environment that broadened and challenged his Cornell training. $\mathrm{He}$ found two interlocutors at Brookings, John Ikenberry and Michael Mastanduno. The three spent hours debating from the distinct intellectual viewpoints that they had inherited from their graduate training. It was at Brookings that Lake discovered the value of creating communities of people with diverse intellectual backgrounds. His conversations to harness a diversity of research perspectives. Lake revealed one of his defining features, as Frieden fondly describes: "He is extraordinarily open-he will read anything, creatively vacuuming ideas, subjecting them to withering analysis," and applying them to his work.

When he started at Cornell, Lake was fascinated by the inherent contradiction he saw in the predictions of hegemonic stability theory (HST). He tackles those questions directly in Power, Protection, and Free Trade. Even in his early work, we start to see a single thread that runs clearly through later publications: order has to be actively created, it is not just a function of formal institutions, but rather leadership and authority are essential factors. Early on, he wrestled with the intuition that there was something about the United States' role in the world that was critical for the construction of international order. He saw that systemic factors alone cannot explain trade policy outcomes, indeed that liberal economic regimes can be (actively) created and maintained in the absence of a hegemon ("Beneath the Commerce of Nations" and "The State and American Trade Strategy in a Pre-Hegemonic Era"), and relatedly, that an open political economy does not require coercion ("The Second Face of Hegemony").

Presaging his work on foreign policy in the 1990s, Lake emphasized the importance of domestic politics. In these early contributions, Lake avoids black boxing the policymaking process (e.g., "Approaches to Explaining American Foreign Economic Policy"). In another iteration, Lake, Ikenberry, and Mastanduno critiqued HST and structural realism generally for not being sensitive to would have a stronger interest in free trade than other states in the system. Although the answers to the challenges proved elusive at the time, Lake would later offer more satisfying responses to some of the questions he had posed.

\section{BUILDING A NEW FOUNDATION} THE CONTRACTING ANALOGY

Dissatisfied with existing political science explanations for hegemonic behavior, Lake's answer came in part from discussions at the UCLA political economy lunches. The Tuesday lunches were born out of a common worldview, desiring theoretical and empirical rigor. One focus of the group was industrial organization, which in the 1970 and 1980 s had spawned many exciting theoretical developments. One Tuesday, Oliver Williamson's “Transaction-cost Economics" set off a series of "ah-ha" moments over lunch. Lake quickly turned to Williamson's The Economic Institutions of Capitalism and Markets and Hierarchies. Applying Williamson's insights about the organization of firms, Lake played out whether and how states might be thought of as firms, and then differentiated between the relations within and between states.

While it was immediately clear the analogy would be a productive foundation, bringing it to earth to build a solid theoretical foundation took more time. Although the implications of these novel theoretical applications portended a disassembly of one of the core assumptions of IR (that relations between states are anarchic), much of Lake's research over the next decade involved playing with, tailoring, advancing, and applying the insights of relational contracting to the 
big puzzles that had captured his imagination. Lake wrestled with the firm and relational contracting in various incarnations: how states interacted with each other as well as how they interacted with their domestic populations. For example, thinking about states as monopoly providers of public goods was not a clean a one-to-one analogy initially, but it provided great insight into how hegemons behave.

With the goal of rigorous deconstruction of some of the most important questions in international politics, Lake has used the core insights of relational contracting. $\mathrm{He}$ applied the analogy to domestic contracting and one of the major debates of the 1990s: the democratic peace. In "Powerful Pacifists," Lake builds a compelling explanation focused on the rent-seeking state. Here, the focus is on how domestic relations (the cost of contracts, or what would eventually become governance costs in "Anarchy, Hierarchy, and the Variety of International Relations" and Entangling Relations) play out biasing states toward war and expansion. In "The Rise, Fall, and Future of the Russian Empire," Lake makes the point that, intellectually, the analogy holds both domestically and internationally. In work with Matthew Baum, also a former student, the frame is turned to the role of political institutions in the provision of public goods ("The Invisible Hand of Democracy") and later how they condition investment in human capital for growth ("The Political Economy of Growth").

In "Anarchy, Hierarchy, and the Variety of International Relations" and Entangling Relations, Lake revisited the major question that started his career: how order in the international system is created and maintained. He uses relational contracting to explain the full range of relations between states as well as the organization of the "industry." This work is a direct challenge to a fundamental tenet of realist and neorealist understandings of the modern state system: that interstate relations are anarchic. Having challenged that foundation, Lake then builds a theory, based on contracting, that offers an understanding of authority through its empirical manifestations, particularly in American foreign policy and security relations more generally.

In addition to research that flows directly from relational contracting and theories of the firm, Lake also engaged in collaborations with significant influence on the field of IR. Strategic Choice and International Relations, coedited with Robert Powell, is a prime example, deploying leading scholars in the field to reflect on post-Cold War international relations. We note that, while pitched at a slightly higher level, many of the core ideas articulated by the contributors are echoed in World Politics: Interests, Interactions, Institutions, the Frieden, Lake, and Schultz collaborative undergraduate text, which has become a cornerstone of undergraduate training in international relations (and political science generally).

After moving to UCSD in 1992, Lake found another set of stimulating collaborators in the department (across all subfields, including Mat McCubbins and Gary Cox) as well as at the School of Global Policy and Strategy (then the School of International Relations and Pacific Studies), principally Peter Gourevitch, Miles Kahler, and Steph Haggard. Together they built one of-if not the-largest concentrations of IR scholars in the world. Lake often speaks fondly of the IR group that came together over the years, and the vibrant intellectual life they fostered. They established a UCSD branch of the UCLA Tuesday political economy lunch group. The regular gathering of rich and varied perspectives is something Lake credits for the development of his work at UCSD. From 1997 to 2001 he and Gourevitch coedited International Organization. In 2006, Lake was named a Fellow of the American Academy of Arts and Sciences. All of this occurred during a time of phenomenal research productivity at UCSD as Lake published his early works on relational contracting and began to solidify what would then emerge as a major plank in IR research around rational choice-the analogy of the firm, and agency in authority.

\section{THE NEXT LEVELS OF CONTRACTING}

If the 1990s saw the development of the major intellectual scaffolding for the relational contracting framework of Lake's research agenda, more recent decades have seen an expansion, renovation, and broad application of a set of microfoundational ideas to an increasingly large set of empirical examples and theoretical questions. Having crafted the definitive statement on relational contracting's usefulness in explaining political behavior and the seemingly puzzling choice for hierarchical relations in US foreign policy, Lake's next major intellectual move was to apply his insights to international politics.

Lake's recent work initiates a "hierarchy turn" in mainstream international relations that fundamentally shifts the orientation of the discipline. The assumption was that anarchy was the organizing principle that shaped international politics, a long-standing belief in IR theory. Challenging this conventional wisdom, Lake argued that hierarchy not only existed between states, but it existed as a matter of choice, and was observable if we knew how to look at it. If hierarchy is so prevalent, what does this say about the distinction between the domestic and international levels? Clearly, some of the same concepts we had taken for granted and assumed only happened within borders-authority, legitimacy, order-were very much happening between borders. The debates that were occurring between "isms," in some ways, came together in Lake's 2009 Hierarchy in International Relations. The book articulated how to rigorously apply the contracting approach to relationships between states. This time, his main goal was to demonstrate how hierarchy, and in turn, authority, are relational concepts that require maintenance and renegotiation. Hierarchy is a continuum, rather than a binary. He identifies the forms of hierarchy that define international relations, and he demonstrates how dominant states must produce benefits for subordinate states. Furthermore, he shows how they are prevented from abusing subordinate states through the recognition that hierarchy is not a constant, but a relationship.

That international hierarchy is a choice for both the dominant and subordinate states-thereby revising the classic Hobbesian insight regarding the ruler and the ruledis the novel point of the book. ${ }^{1}$ As before, Lake walks through the many alternatives to his conception of hierarchy and authority before explaining the tradeoffs with his choice. And though hierarchy is not new, few mainstream scholars of IR viewed the world through this lens.

The years between Entangling Relations and Hierarchy were coupled with major institution-building efforts in critical service roles at his university. In the early 20oos, Lake served as department chair at UCSD, and followed by service as associate dean in the Division of Social Sciences from 2006 to 2015, and acting dean of social sciences from 2011 to 2012. He was named the Jerri-Ann and Gary E. Jacobs Professor of Social Sciences in 2010. In those same years, dozens of Lake's students landed in tenure-track positions, armed with his advice about bargaining, knowing his support was a phone call away.

As Hierarchy began hitting course syllabi and reaching a wide audience of IR in North America, Europe, and beyond, Lake 
turned his attention to another topic that he had long railed against in his teaching: the dominance of "paradigms" in IR. The first edition of the Frieden, Lake, and Schultz textbook came out in 2009 (now in its third edition) devoted a handful of lines to a "debate" between realism, liberalism, and constructivism that defined the IR world to novices and many researchers alike. Instead of diving into the merits of the assumptions of each of these isms, Lake and his coauthors sought to teach undergraduates how to think about problems, how to use conceptual tools such as bargaining to understand why policies fail and why bad things happen, and demonstrate how rigid paradigms can cloud the fundamental issues that many of us who get into IR care deeply about.

Lake followed up the release of the text with an essay entitled: "Why 'Isms' are Evil," where he explained how using the engagement with the isms creates self-reaffirming sects within political science that do not advance our understanding of IR. In a related piece, "Theory is Dead, Long Live Theory," Lake spelled out how the so-called Great Debates preoccupation in IR has actually occluded the significant progress made in the field on mid-level theorization that has led to agendas such as the democratic peace and open-economy politics. It was at this time that UCSD recognized Lake's many accomplishments with the 2013 Chancellor's Associates Award for Excellence in Research in Humanities and Social Sciences.

More recently, Lake has returned, in some ways, to familiar grounds, albeit with a different frame of mind. His early forays into HST reflected his interest in order, and more specifically, how the powerful play a role in building and maintaining the order they want. Although the questions he raises now are different from those in his early years, fundamentally the questions of the costly ways that the powerful try to manipulate the world in their own interests shapes his recent inquiries. These inquiries include a renewed focus on how domestic politics are shaped by international hierarchy ("Legitimating Power") and as well as ongoing collaborative work with a group of UCSD graduate students on "proxy wars" or how the United States acts on the world indirectly by shaping the incentives of foreign leaders.

His 2016 book, The Statebuilder's Dilemma, explores the tragic observation that statebuilding is both important for international affairs and notoriously difficult to accomplish. Why is it, if failed or weak states create more insecurity for everyone, that so few states are willing to help in the reconstruction their besieged counterparts? What causes many of the statebuilding efforts to fail? Lake argues that it is because the interests of the statebuilders are often at odds with those for whom the state is being built. Statebuilders must rely on loyal (but often nonrepresentative) agents within states to help with the process, but in so doing struggle to get the necessary buy-in from the rest of the population to actually make the state function once built. In contrast to those who insist on getting the institutions right, Lake shows how institutions must rest in societal relations. Taking the examples of Iraq and Somalia, Lake extends the relational contracting framework from his earlier books, this time outlining how consent can be elusive when outsiders intervene in fractured contexts.

\section{A BUILDER OF COMMUNITIES AND INDIVIDUALS}

If you ask Lake why he feels the strong urge to serve the political science community beyond his numerous writings, his response is quick. To him, political science and IR have permitted him to explore some of the most important questions in politics. $\mathrm{He}$ also feels he has been a great beneficiary of the community. Service is a way to give back to a discipline which has given him such a lengthy and rewarding career and so much personal satisfaction.

What Lake fails to mention with his characteristic modesty, however, is how the field of political science has benefitted from the rigor, intellectual-creativity, and magnanimity he brings. More importantly, many individuals have directly reaped the rewards of his publications, pavement pounding, and advice. We know this directly, and feel that we speak accurately for our fellow Lake students ("our siblings") when we discuss how Lake has consistently shown us the value of conviction, the rewards of generosity, and the advantages of seeing holistically.

\section{Building Community through Fostering Conversations}

In fall 2005, the International Political Economy Society (IPES) was an inkling of an idea in an e-mail to some close collaborators. Lake wanted to create a forum for international political economy (IPE) scholars to share their research, modeled after the Peace Science Society. The very first IPES meeting took place in 2006. Attendees chose between a few rooms where simultaneous, short presentations were given by authors, followed by deep engagement by the audience. Intended to develop, expand, and improve work in political economy, IPES has had the effect of creating a community for IPE researchers where none existed. It has had a particular focus on providing opportunities for junior scholars to present their research. In recent years, there have been virtual IPES meetings that supplement the yearly gathering.

Having successfully launched a community that brought people with similar backgrounds together, Lake has also been a strong advocate of diversity within IR. He has distinguished himself as a mentor of emerging female scholars in the discipline (a remarkably high proportion of his advisees are women), receiving the Society for Women in Political Economy (SWIPE) Outstanding Mentor Award presented annually at ISA. Many of the women he has advised recall his careful navigation of gendered assumptions about his students, particularly when they go on the job market and otherwise make important life decisions. Lake is a role model for how to mentor women, simultaneously as scholars and as individuals whose personal lives might careen into their academic ambitions. Past collaborator and fellow International Organization board member Janice Stein reflects, "David has given generously of his time and advice to colleagues in the field. Especially noteworthy is his mentorship of women in all aspects of their academic lives. He has been a supporter, cheerleader, advisor, and advocate for many women colleagues at critical moments in their careers. His support has been quiet, effective, and exemplary."

At UCSD, Lake was one of the main forces behind the formation of the annual IR Retreat, a day-long meeting of faculty and advanced graduate students. In focused panels, presenters discuss progress on their dissertations and receive commentary from non-advisory faculty. The alumni of these retreats always emerge with a wealth of suggestions that would otherwise not happen in occasional hallway conversations.

\section{Building Knowledge through Open- Mindedness}

Any casual reader of Lake's CV should note that not only has he published furiously since 1983 , but that his work, unusually, spans the three major subject areas of IR-security, IPE, and institutions/governance. They are not small forays into the areas either-indeed, Lake began with IPE, spread his interest into security, and created 
new ways of thinking about global governance. His work is published across all of the major journal and book publishers in the discipline. The dexterity of his publication record shows the open-mindedness through which he approaches his work. It isn't just mantra, but it is the Lake way.

One way to look at this more carefully is in his collaboration. Lake publishes many single-authored pieces, but he also assiduously launches and agrees to participate in collaborative projects. He has published 10 edited volumes (all but one coedited), with a couple more in the pipeline. His success at publishing edited volumes speaks to both the enthusiasm of collaborators to work with him as well as Lake's ability to apply analytical lenses to a wide variety of topics. The great majority of these edited collections are published by top presses in the field. Lake uses these opportunities to learn more about the research on particular topics and approaches in the field.

The participants on his edited collections also benefit tremendously from his guidance
Darren Hawkins, and Michael Tierney on Delegation, to name just a few.

\section{Building Careers, Building up Students}

One uncanny ability Lake has is to read the field broadly, both well beyond the literatures he frequently contributes to and generally keeping abreast of the literature, likely the result of his extraordinarily curious and open mind. He understands how interesting questions fit together theoretically and their contribution to our broader understanding of political phenomena. To convey this, he tries to help others locate the anomalous, telling scholars of all levels alike, "Find something that shouldn't happen." It is then the job of the scholar to provide compelling answers with rigorous evidence appropriate to the question. In graduate seminars, he would take the unusual step of admitting when he didn't know the answer to a question and then work through possibilities with the class. In part by example, he teaches his students and those sets of students. A particularly fertile course for producing dissertation ideas, students came up with new directions for research on the topics of authority and order. Lake and Kahler, who frequently cochaired or sat as second readers for one another's students, prodded contributions by encouraging new combinations of existing ideas.

Those who know Lake personally do not find it surprising so many students spend Tuesday afternoons at his office hours, an established institution at UCSD. Students of many different intellectual stripes camp out for an early place in line to get help tackling their questions and sharpening their ideas. In spite of their popularity, meetings are never rushed as Lake takes time to work analogies through, weigh evidence, and dispense advice on appropriate next steps. Notably, he never closes up shop until the last one in line has a turn. Lake always focuses his attentions on the questions at hand, and no one ever leaves his office empty-handed for suggestions. Likewise, conference participants who meet with Lake benefit from his

\section{Any casual reader of Lake's CV should note that not only has he published furiously since 1983, but that his work, unusually, spans the three major subject areas of IR-security, IPE, and institutions/governance.}

and feedback, as both of us can attest. One function of edited volumes is to present either wider or deeper analyses of topics than any singular effort can provide. As anyone who has participated in one of these efforts knows, the other effect of edited collections is to bring people who had previously had little to no contact together to think collectively about a set of questions. Lake has also been part of the crowd in many instances, contributing chapters to collective efforts. Yet, Lake's presence in any collective project makes it better; he has an unprecedented ability to package and repackage so that even seemingly disparate ideas fit together into coherent theoretical frameworks. His own contributions always link well to the editors' intentions while providing a unique perspective.

Finally, Lake has had a diverse set of coauthors in political science. Frequent collaborators, such as Frieden or Kahler, are rare. Instead, as Lake's career matured, he began reaching out to an ever wider net of coauthors, first with Michael Mastanduno and G. John Ikenberry, then with Donald Rothchild on the ethnic conflict project, Robert Powell on strategic choice, and Dan Nielson, how to approach a new or difficult problem, and he excels at taking a theory that he has found convincing in one substantive area and applying it to an entirely new subject to add analytic clarity and derive observable implications. One of Lake's trademark pieces of advice is to let ideas "percolate."

Lake and Kahler put percolation to work in a PhD course they cotaught on international authority. While the foundation of the course was their past collective thinking on empire and global governance, the purpose of the course was to think through these issues together. In the process, they modeled productive debate and collaboration for generations of their students. Kahler captures this dynamic aptly, noting, "For someone dedicated to the importance of hierarchy in international politics, David is one of the least hierarchical senior scholars in our profession. For David, everyone is a colleague, a potential collaborator, or a source of new insights. Although he has very clear views, clearly presented, he does not impose them on others, inside or outside the classroom." Indeed, some of the key insights for Hierarchy in International Relations came during seminar, working through key issues with Kahler curious and agile mind working through a research dilemma from the point of view of the researcher, not his own.

This intellectual curiosity and openness is reflected in the diversity of the research interests of his students since Cheryl Schondhardt-Bailey-his first PhD student at UCLA who, notably, began her work on Britain's Corn Laws in part because she was convinced that Lake and his versions of HST that he was then working on were fundamentally wrongheaded. He has advised students working in other areas familiar to him, such as US foreign policy, diplomacy, trade, conflict and occupation, authority, and domestic sources of IR, using case-based, game theoretic, and statistical methods. But he has also invested heavily in students working on international norms, non-proliferation, multilateralism, elections, civil war, and conflict resolution, to name a few topics, and he always encouraged and supported students whose questions led them to experimental and computational methods, or constructivist explanations. Lake has also advised students whose $\mathrm{PhDs}$ were in economics. To date, he has been part of 56 completed $\mathrm{PhDs}$, and currently has some 14 students in progress. 
Lake's ambition is to leave his mark on the field from helping others and having helped students. Given the overwhelming, and still growing, volume and level of importance his work imparts on our understanding of where international order comes from and why it is structured the way it is, perhaps this is an easy position to take. After all, Lake's thinking has shaped responses, whether positive or negative, for several decades.

Teaching and advising are often the unsung part of our work, and they are what sets Lake apart. His strengths in teaching are tremendous; his personal commitment, truly remarkable. He shares in moments of success, just as he has shared in times of struggle. Almost all of Lake's students have personal memories of consulting with Lake-and often his wife Wendy, who is well-known to and extremely supportive of his students- in moments of crisis or tough decisions. Lake makes himself available, even when traveling or caught in a day's worth of meetings. He makes it clear that his mentorship does not end with convocation, and through him, all who have enjoyed his unique approach to supporting young academics are highly connected. He tells students that the only form of payback he accepts is that they pay it forward.

\section{BUILDING FORWARD}

To summarize Lake-and his many accomplishments and contributions since his early days-is difficult. Yet, many things stay the same. Katzenstein, who graciously provided insight into Lake's progression as a scholar, offered many of the identical adjectives of many of Lake's graduate students (and colleagues): "Focused ... wonderful mentor and supporter of students and younger colleagues, great colleague who creates public goods, modest, prodigious worker, always ready for an intellectual challenge, generous ... good judgement, common sense, a good influence on all around him, good listener, inquisitive." Gourevitch echoes these sentiments, reflecting that "Lake is insufficiently appreciated as an all around 'great man' in our field. Being elected as president of the APSA is wonderfully appropriate for someone who contributes so much in a modest unassuming manner."
These consistent qualities have propelled Lake to the forefront of political science scholarship, and as he assumes the leadership of APSA for 2016-2017, his natural interest in the way organizations work (and building them) will serve him and the association well. He has already served the association in many capacities, from section organizer to program chair, from rules committee chair to APSA Council. Lake's many experiences as administrator and organizer in other contexts-ISA, UCSD, IPES, journals, and other more informal gatherings-position him to highlight some critical issues, as APSA must address continuing challenges in terms of diversity, globalization, and the future of research and the academy..

\section{ACKNOWLEDGEMENTS}

We thank Jeffry Frieden, Peter Gourevitch, Miles Kahler, Peter Katzenstein, Janice Gross Stein, and our many academic siblings for their generous assistance in writing this piece. We also thank Danielle Villa and Takumi Shibaike for research assistance.

\section{NOTES}

1. See 2010 review by Michael Barnett in the Journal of Politics 72 (3): 912-14

\section{REF E R E N C E S}

Barnett, Michael. 2010. Review: "Hierarchy in International Relations. By David Lake." Journal of Politics 72 (3): 912-14

Baum, Matthew A., and David A. Lake. 2003. "The Political Economy of Growth: Democracy and Human Capital." American Journal of Political Science 47 (April): 333-47.

Frieden, Jeffry A., David A. Lake, and Kenneth A. Schultz. 2009. World Politics: Interests, Interactions, and Institutions. New York: W. W. Norton.

Gilpin, Robert. 1976. US Power and the Multinational Corporation: The Political Economy of Foreign Direct Investment. London: Macmillan.

Ikenberry, G. John, David A. Lake, and Michael Mastanduno. 1988. "Introduction: Approaches to Explaining American Foreign Economic Policy." International Organization 42 (Winter): 1-14.

James, Scott C., and David A. Lake. 1989. "The Second Face of Hegemony: Britain's Repeal of the Corn Laws and the American Walker Tariff of 1846." International Organization 43 (Winter): 1-29.

Katzenstein, Peter. 1978. Between Power and Plenty: Foreign Economic Policies of Advanced Industrial States. Madison: University of Wisconsin Press.

Katzenstein, Peter. 1985. Small States in World Markets: Industrial Policy in Europe. Ithaca, NY: Cornell University Press.
Lake, David A. 1996. "Anarchy, Hierarchy and the Variety of International Relations.” Internationa Organization 50 (Winter): 1-33

Lake, David A. 1984. "Beneath the Commerce of Nations: A Theory of International Economic Structures." International Studies Quarterly 28 (June): 143-170.

Lake, David A. 1999. Entangling Relations: American Foreign Policy in its Century. Princeton, NJ: Princeton University Press.

Lake, David A. 2009. Hierarchy in International Relations. Ithaca, NY: Cornell University Press.

Lake, David A., and Matthew A. Baum. 2001. "The Invisible Hand of Democracy: Political Control and the Provision of Public Services." Comparative Political Studies 34 (August): 587-621.

Lake, David A. 1993. "Leadership, Hegemony, and the International Economy: Naked Emperor or Tattered Monarch with Potential." International Studies Quarterly 37 (December): 459-89.

Lake, David A. 2009. "Open Economy Politics: A Critical Review." Review of International Organization $4(3): 219-44$

Lake, David A. 1992. "Powerful Pacifists: Democratic States and War." American Political Science Review 86 (March): 24-37.

Lake, David A. 1988. Power, Protection, and Free Trade: International Sources of US Commercial Strategy, 1887-1939. Ithaca, NY: Cornell University Press.

Lake, David A. 1997. "The Rise, Fall, and Future of the Russian Empire: A Theoretical Interpretation" In The End of Empire? The Transformation of the USSR in Comparative Perspective, eds. Karen Dawisha and Bruce Parrott. New York: M.E. Sharpe.

Lake, David A. 1988. "The State and American Trade Strategy in the Pre-Hegemonic Era." International Organization 42 (Winter): $33-58$.

Lake, David A. 2016. The Statebuilder's Dilemma: On the Limits of Foreign Intervention. Ithaca, NY: Cornell University Press.

Lake, David A., and Robert Powell. 1999. Strategic Choice in International Relations. Princeton, NJ: Princeton University Press.

Lake, David A. 2013. "Theory is Dead, Long Live Theory: The End of the Great Debates and the Rise of Eclecticism in International Relations." European Journal of International Relations 19 (3): 558-78.

Lake, David A. 2011. "Why "Isms" are Evil: Theory, Epistemology, and Academic Sects as Impediments to Understanding and Progress." International Studies Quarterly 55: 465-80.

Mastanduno, Michael, David A. Lake, and G. John Ikenberry. 1989. "Toward a Realist Theory of State Action.” International Studies Quarterly 33 (December): 457-74.

Waltz, Kenneth. 1979. Theory of International Politics. Reading: Addison-Wesley Publishers.

Williamson, Oliver. 1985. The Economic Institutions of Capitalism: Firms, Markets, Relational Contracting. New York: Free Press.

Williamson, Oliver. 1983. Markets and Hierarchies: Analysis and Antitrust Implications. New York: Free Press.

Williamson, O.E. 1979. "Transaction-Cost Economics: The Governance of Contractual Relations." The Journal of Law and Economics 22 (2): 233-61. 